\title{
Kampung Semangga Jaya Sebagai Sentra Produksi Pakan Ternak Sapi
}

\author{
Abdul Rizal1*, Fredy², Adrianus ${ }^{3}$, Ineke Nursih Widyantari ${ }^{4}$ \\ 1,2,3,4, Universitas Musamus, Merauke, Indonesia \\ *Corresponding Author: 89abdulrizal@gmail.com
}

\begin{abstract}
Info Artikel Diterima : 28/10/2021
Direvisi: 30/10/2021

Disetujui: 05/11/2021

Abstract.Semangga Jaya Village, Merauke Regency as one of the villages that has high rice productivity. In 2019 rice production was 55,184.34 tons with a harvested area of 9,614 hectares. This figure is a potential benefit for the community. However, the high production of rice is not followed by the interest of farmers in utilizing rice straw waste to be processed into products that have high economic value, namely into complete feed that can be used as cattle feed. Cattle farming business is currently starting to be developed by farmers, although in practice it has not been fully maximized. This is due to the lack of public understanding of cattle development and the feeding system used is still simple or uses rice straw which basically has a high crude fiber content. The implementation of this activity will provide full participation in solving problems faced by cattle farmer groups, especially the feed processing system by utilizing rice straw waste into complete feed. Semangga Jaya Village, Merauke Regency in the future can be used as a center for cattle feed production. The implementation of activities includes counseling and technical guidance as a medium for transferring knowledge and technology to partners, which will be carried out en masse, through groups and individuals while still implementing Covid-19 health protocols. The solutions offered in the implementation of the program are through non-physical and physical activities. It is hoped that (a) Increased knowledge and skills of farmers regarding the system for processing rice straw waste into complete feed, (b) Increased knowledge and skills in feeding cattle by looking at feed quality standards, (c) Increased knowledge and ability of farmers and breeders to produce feed into attractive packaging for sale through offline and online systems.
\end{abstract}

Keywords: Rice Straw, Fermentation, Feed, Cattle

\begin{abstract}
Abstrak. Kampung Semangga Jaya sebagai salah satu kampung yang memiliki produktivitas padi yang tinggi di Kabupaten Merauke. Pada tahun 2019 produksi padi sebesar 55.184,34 ton dengan luas panen 9.614 hektar. Angka ini merupakan potensi yang menguntungkan bagi masyarakat Kampung Semangga Jaya. Akan tetapi tingginya produksi padi tidak diikuti dengan minat petani dalam memanfaatkan limbahnya khususnya jerami untuk diolah menjadi produk yang memiliki nilai ekonomis yaitu menjadi pakan komplit yang dapat digunakan sebagai pakan ternak sapi. Usaha peternakan sapi saat ini mulai dikembangkan oleh peternak meskipun dalam pelaksanaanya belum sepenuhnya maksimal. Hal ini disebabkan karena kurangnya pemahaman masyarakat terhadap pengembangan ternak sapi masih terbatas serta sistem pemberian pakan yang digunakan masih bersifat sederhana atau menggunakan jerami padi yang sifat dasarnya memiliki kandungan serat kasar yang tinggi. Pelaksanaan kegiatan ini akan memberikan partisipasi penuh terhadap penyelesaian masalah-masalah yang dihadapi kelompok peternak sapi, khsususnya sistem pengolahan pakan dengan memanfaatkan limbah jerami padi menjadi pakan komplit. Diharapkan kedepannya Kampung Semangga Jaya menjadi sentra Produksi Pakan di Kabupaten Merauke. Pelaksanaan kegiatan meliputi penyuluhan dan bimbingan teknis sebagai media transfer pengetahuan dan teknologi kepada mitra, yang akan di lakukan secara massal, melalui kelompok dan perorangan dengan tetap menerapkan protokoler kesehatan Covid-19. Solusi yang ditawarkan dalam pelaksanaan program Pengembangan Desa Mitra di Kampung Semangga Jaya adalah melalui kegiatan non fisik dan fisik. diharapkan (a) Meningkatnya pengetahuan dan keterampilan peternak mengenai sistim pengolahan limbah jerami padi menjadi pakan komplit, (b) Meningkatnya pengetahuan dan keterampilan dalam pemberian pakan pada ternak sapi dengan melihat standar baku mutu pakan, (c) Meningkatnya pengetahuan dan kemampuan petani dan peternak memproduksi pakan menjadi kemasan menarik untuk dijual melalui sistem offline dan online.
\end{abstract}

Kata Kunci: Jerami Padi, Fermentasi, Pakan, Ternak Sapi

How to Cite: Rizal, A., Fredy, F., Adrianus, A., \& Widyantari, I.N. (2021). Kampung Semangga Jaya Sebagai Sentra Produksi Pakan Ternak Sapi. Prima Abdika: Jurnal Pengabdian Masyarakat, 1(4), 167-173. https://doi.org/10.37478/abdika.v1i4.1305

Copyright (c) 2021 Abdul Rizal, Fredy, Adrianus, Ineke Nursih Widyantari. This work is licensed undera Creative Commons Attribution-ShareAlike 4.0 International License.

\section{Pendahuluan}

Jumlah penduduk di Kampung Semangga Jaya dari tahun ketahun mengalami peningkatan dengan jumlah tahun 2019 yaitu 2.925 dan bertambah pada tahun 2020 menjadi 2.943 jiwa dengan laju pertumbuhan 0,62\% (BPS, 2020). Kondisi ini merupakan salah satu faktor yang menjadikan usaha pertanian khususnya tanaman padi dalam memberikan ruang tersendiri untuk diversifikasi usaha pertanian berkelanjutan. 
Peningkatan jumlah penduduk diyakini akan meningkatkan permintaan dan konsumsi tanaman pangan khususnya padi.

Kampung Semangga Jaya sebagai salah satu kampung yang memiliki produktivitas padi yang tinggi di kabupaten Merauke. Pada tahun 2019 produksi padi sebesar 55.184,34 ton dengan luas panen 9.614 hektar (BPS, 2020). Angka ini merupakan potensi komersial yang menguntungkan bagi masyarakat Kampung Semangga Jaya. Tingginya minat masyarakat dalam melakukan usaha tanaman padi disebabkan karena usaha turun temurun dan mayoritas masyarakatnya hidup sebagai petani. Kondisi obyektif di atas menjadikan Kampung Semangga Jaya sebagai salah satu kampung yang memberikan sumbangsih besar terhadap swasembada beras di Kabupaten Merauke.

Tingginya produksi padi tidak diikuti dengan minat petani dalam memanfaatkan limbahnya khususnya jerami untuk diolah menjadi produk yang memiliki nilai ekonomis yaitu menjadi pakan komplit yang dapat digunakan sebagai pakan ternak sapi. Berdasarkan data dan survey awal di lapangan bahwa ternak sapi banyak dipelihara oleh masyarakat yang diusahakan bersamaan dengan tanaman padi. Hal ini disebabkan karena usaha ternak sapi mudah dilakukan baik berorientasi pada skala rumah tangga maupun usaha besar. Mudahnya usaha ternak sapi dapat dilihat dari segi pemeliharaannya, kemampuan ternak menyesuaikan dengan lingkungan, tidak gampang terserang penyakit serta harga jual ternak sapi yang relatif tinggi (Alvianti Bawinto et al., 2016).

Usaha peternakan sapi saat ini mulai dikembangkan oleh peternak meskipun dalam pelaksanaanya belum sepenuhnya maksimal. Hal ini disebabkan karena kurangnya pemahaman masyarakat terhadap pengembangan ternak sapi masih terbatas (Rachmawati, 2011). Indikator ini dapat dilihat dengan sistem manajemen pemeliharaan yang kurang maksimal serta tidak berorientasi pada sistim agribisnis. Indikasi yang lain yaitu sistim pemberian pakan yang digunakan masih bersifat sederhana atau menggunakan jerami padi yang sifat dasarnya memiliki kandungan serat kasar yang tinggi (Yanuartono et al., 2019). Konsekuensi dari pemberian pakan ini mengakibatkan ternak sapi yang dipelihara mengalami penurunan bobot badan (kurus) karena pakan yang digunakan belum memenuhi standar nutrusi pakan yang sesungguhnya atau hanya mengandalkan jerami padi (Eko et al., 2012). Usaha ternak sapi yang dilakukan oleh peternak bersifat tradisional dengan mengumpulkan ternak sapi dalam satu kawasan sempit untuk dipelihara sehingga mengakibatkan ternak sapi kekurangan nutrisi dan menyebabkan stres.

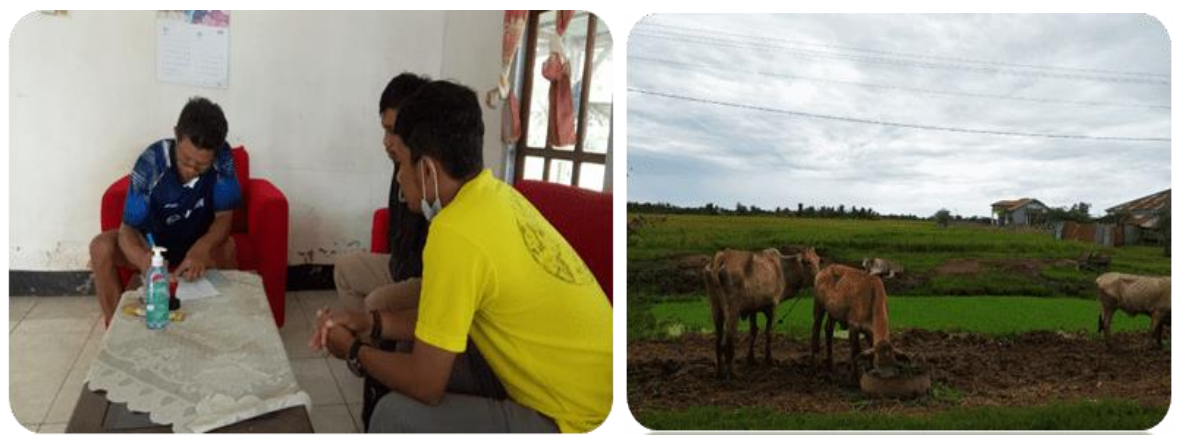

Gambar 1. Kondisi Obyektif Lapangan 
Hadirnya program Pengembangan Desa Mitra (PDM) merupakan solusi untuk menjawab persoalan-persoalan yang dihadapi oleh mitra khususnya di Kampung Semangga Jaya. Fokus pengabdian pada mitra yaitu sistem pengolahan pakan dengan memanfaatkan limbah jerami padi menjadi pakan komplit. Dari kegiatan ini dapat diharapkan perubahan yang signifikan dalam aspek pemanfaatan limbah jerami dan menjadikan Kampung Semangga Jaya sebagai sentra produksi pakan sehingga menjadi percontohan untuk pengembangan ternak sapi maupun sistim pengolahan limbah jerami padi menjadi pakan komplit ternak sapi.

\section{Metode Pelaksanaan}

Metode pendekatan untuk menyelesaikan persoalan mitra di Kampung Semangga Jaya adalah (a) Kegiatan Non Fisik. Bimbingan teknis dan penyuluhan masuk dalam aspek kegiatan non fisik dan dilakukan sebagai sarana atau media dalam meningkatkan pengetahuan dan teknologi kepada mitra. Bahan yang ditawarkan kepada mitra yaitu manajemen kelembagaan, pengenalan terhadap pemanfaatan limbah pertanian sebagai pakan komplit dan strategi pemasaran. Teknik pelaksaaan di lakukan dengan cara berkelompok dan perorangan serta mengikuti protokoler kesehatan Covid-19. (b) Kegiatan Fisik. Pelaksanaan kegiatan fisik dilakukan melalui demplot dan pendampingan dengan cara pendekatan kekeluargaan dan solidaritas. Adapun kegiatan yang akan dilaksanakan sebagai berikut:

1. Demplot formulasi pakan dengan memanfaatkan limbah jerami padi sebagai pakan komplit

2. Pendampingan penggunaan pakan komplit untuk diberikan pada ternak sapi.

3. Pendampingan pemasaran pakan komplit melalui sistem offline dan online

Agar mendapatkan target yang telah disepakati oleh tim maka kegiatan PDM ini akan dilaksanakan dengan tahapan sebagai berikut:

1. Sosialisasi Program

Tahapan awal yang dilakukan sebelum memperkenalkan kegiatan ini pada mitra yaitu melalukan kesepakatan dengan pemerintah setempat yang dibuktikan dengan surat pernyataan kesediaan kerjasama mitra. Selanjutnya melibatkan berbagai macam unsur yang ada di Kampung Semangga Jaya seperti, tokoh masyarakat, tokoh agama, tokoh pemuda dan yang paling utama adalah peternak yang dapat dijadikan sebagai obyek kegiatan. Tujuan dari kegiatan ini adalah menyamakan ide serta mendapatkan dukungan dari pemerintah setempat. Dalam sosialisasi ini diikutkan dengan pembahasan serta penetapan rencana kegiatan bersama mitra.

2. Pelaksanaan Kegiatan

Pelaksanaan kegiatan dalam program ini dilakukan dengan dua cara yaitu kegiatan non fisik dan kegiatan fisik.

\section{Evaluasi Kegiatan dan Monitoring}

Evaluasi kegiatan dan monitoring dapat dilaksanakan satu bulan sekali agar mengetahui masalah-masalah yang terjadi serta perkembangan program 
yang dilakukan pada mitra. Harapan dari program ini adalah meminimalisir masalah dan memaksimalkan faktor penunjang terhadap program PDM.

\section{Pelaporan Program}

Pelaporan program PDM ini dilakukan melalui dokumentasi dan catatan harian serta dilaporkan melalui website SIMLITABMAS UNMUS. Sistim pelaporan dilakukan dengan dua tahap yaitu laporan kemajuan dan laporan akhir.

\section{Hasil dan Pembahasan}

Pelaksanaan program mengikuti tahapan yang telah direncanakan. Diawali dengan perizinan kepada Kepala Kampung Semangga Jaya. Pada dasarnya mereka mendukung kegiatan tersebut sebagai upaya untuk pengembangan ternak sapi dengan memanfaatkan limbah jerami sebagai pakan ternak.

\section{Kunjungan kepada Mitra PDM}

Kegiatan pengabdian yang telah dilaksanakan yaitu tim pengabdian melakukan kunjungan dan berdiskusi kepada Kepala Kampung Semangga Jaya. Kunjungan yang dilakukan tim pengabdian ini yaitu memberikan informasi tentang inovasi-inovasi yang terbaru yang belum diketahui oleh masyarakat. Selain itu, mencari waktu untuk kesepakatan dalam pelaksanaan pengabdian yang iawali dengan penyuluhan di Kantor Kampung Semangga Jaya.
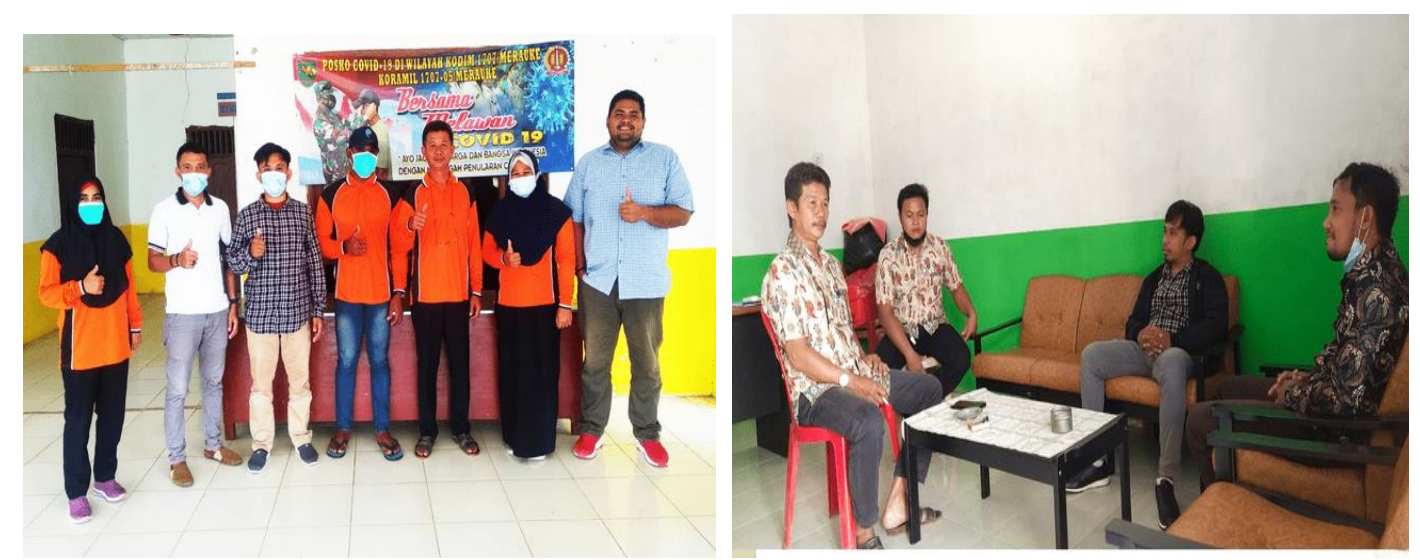

Gambar 2. Kunjungan dan Diskusi Dengan Kepala Kampun Semangga Jaya

2. Pembelian Alat dan Bahan

Setelah menetapkan waktu dengan Kepala Kampung untuk pelaksanaan pengabdian, tim pengábdian mempersiapkan alat dan bahan yang yang berupa sekop, pacul, parang, gembor, terpal, EM4, Molases, Konsentrat, Garam, serta membuat spanduk untuk digunakan saat penyuluhan. Pembuatan spanduk dilakukan untuk memberikan tanda bahwa di tempat akan dilakukan kegiatan Pengabdian Pengembangan Desa Mitra (PDM). 

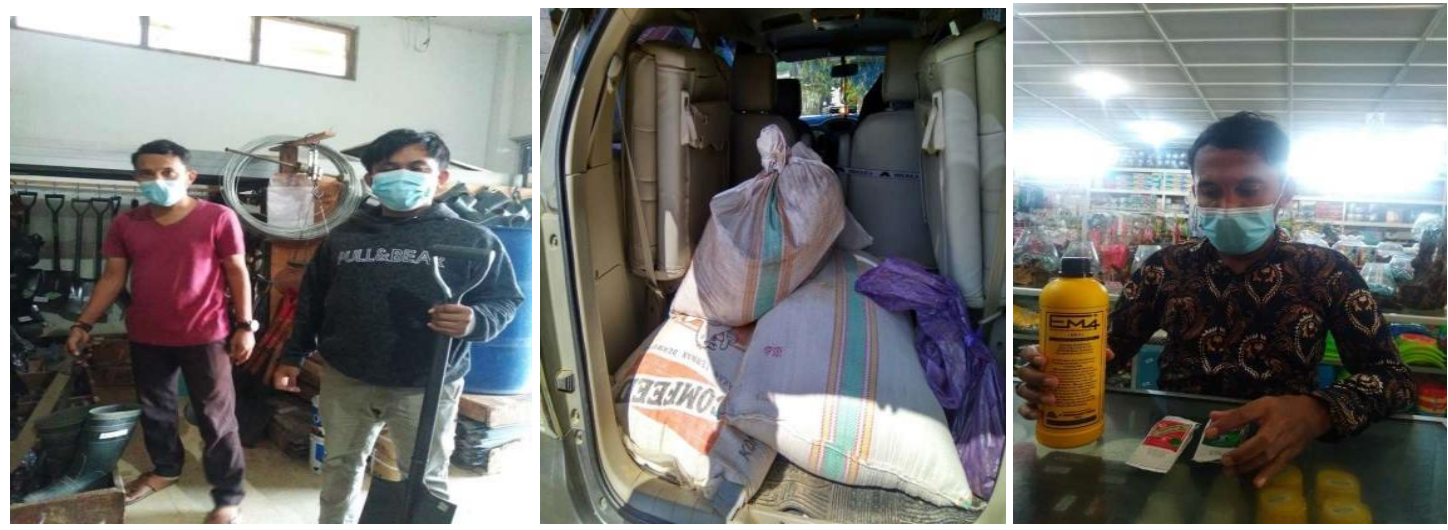

Gambar 3. Pembelian Alat dan Bahan

\section{Pelaksanaan Penyuluhan}

Kegiatan penyuluhan merupakan kegiatan utama dalam pengabdian Pengembangan Desa Mitra (PDM). Setelah diberikan materi selanjutnya dilakukan Demonstrasi Plot (Demplot) terkait pemanfaatan jerami padi sebagai pakan ternak komplit. Kegiatan ini bertujuan memberikan pemahaman kepada masyarakat mengenai manfaat jerami padi sebagai pakan ternak sapi. Dalam kegiatan ini diikuti oleh petani dan peternak yang memang memelihara sapi juga memiliki lahan sawah. Kegiatan ini berdampak positif bagi petani dan peternak karena selama ini belum memanfaatkan jerami padi sebagai pakan ternak. Limbah jerami padi lebih banyak dibakar dan tidak termanfaatkan.

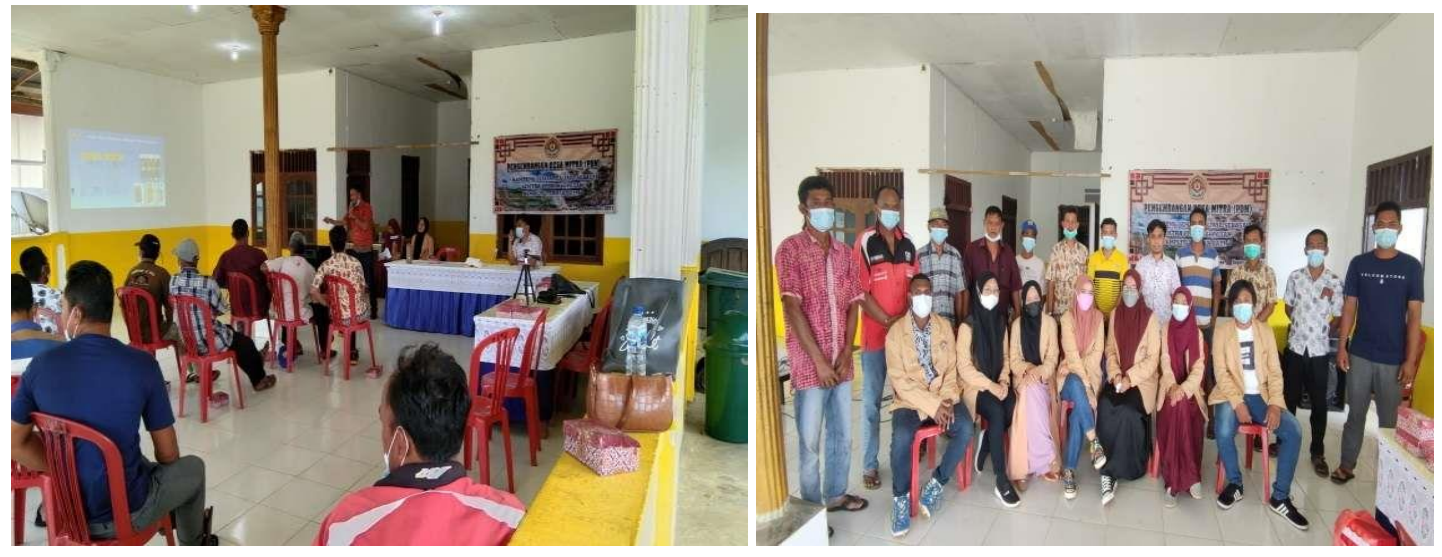

Gambar 4. Penyuluhan di Kantor Kampung Semangga Jaya

\section{Pelaksanaan Demosntrasi Plot (Demplot)}

Tim pengabdian melakukan demonstrasi langsung dihadapan petani dan peternak tentang proses pembuatan pakan komplit melalui fermentasi. Kegiatan ini dipraktekkan oleh tim pengabdian di Kantor Kampung Semangga Jaya. Selain petani dan peternak, Kepala Kampung ikut menyaksikan proses pembuatan pakan fermentasi. Setelah proses perlakuan, maka jerami disimpan dalam bentuk kendap udara dengan tujuan agar proses fermentasi berhasil dan akan dibuka kembali setalah 30 hari. 

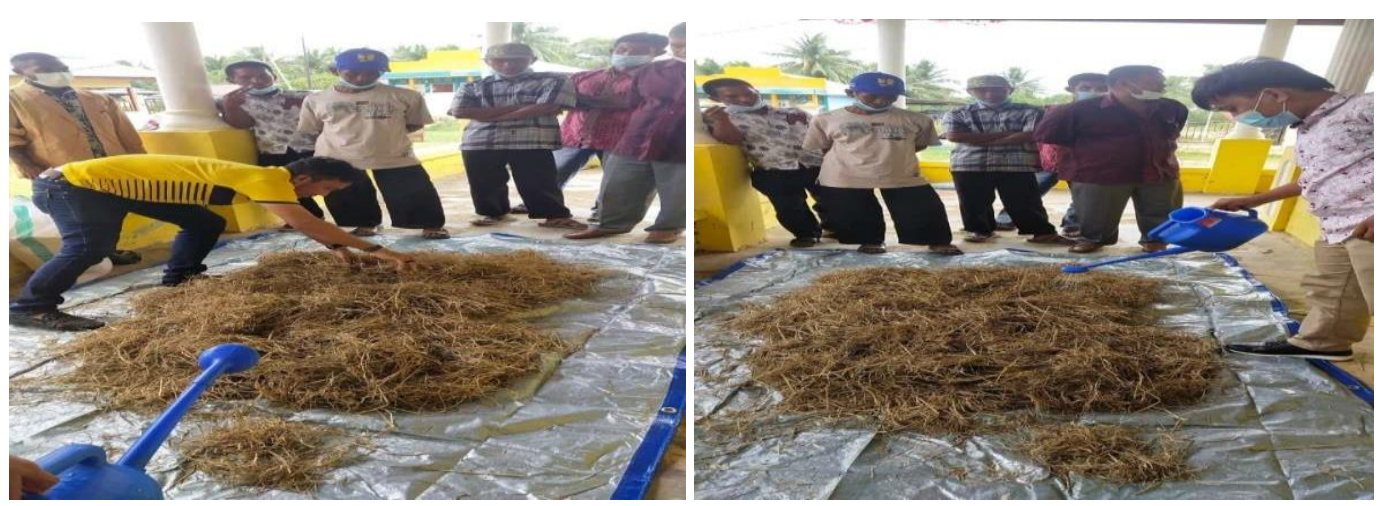

Gambar 5. Pelaksanaan Fermentasi Jerami Padi Untuk Pakan Ternak Sapi

\section{Monitoring dan Evaluasi}

Aktifitas monitoring dan evaluasi dapat memberikan informasi tentang kemajuan dan hasil dari suatu kegiatan yang dilaksanakan. Kegiatan ini diperlukan agar kesalahan awal dapat segera diketahui dan dapat dilakukan tindakan perbaikan. Dalam kegiatan ini, monitoring dilakukan untuk melihat hasil fermentasi jerami padi yang dilakukan oleh tim pelaksana yang disimpan selama 30 hari sebelum diberikan kepada ternak sapi. Dari hasil evaluasi menunjukkan bahwa proses fermentasi telah berhasil dilakukan yang ditandai dengan pemberian pakan fermentasi terhadap ternak sapi dan telah dikonsumsi oleh ternak sapi.
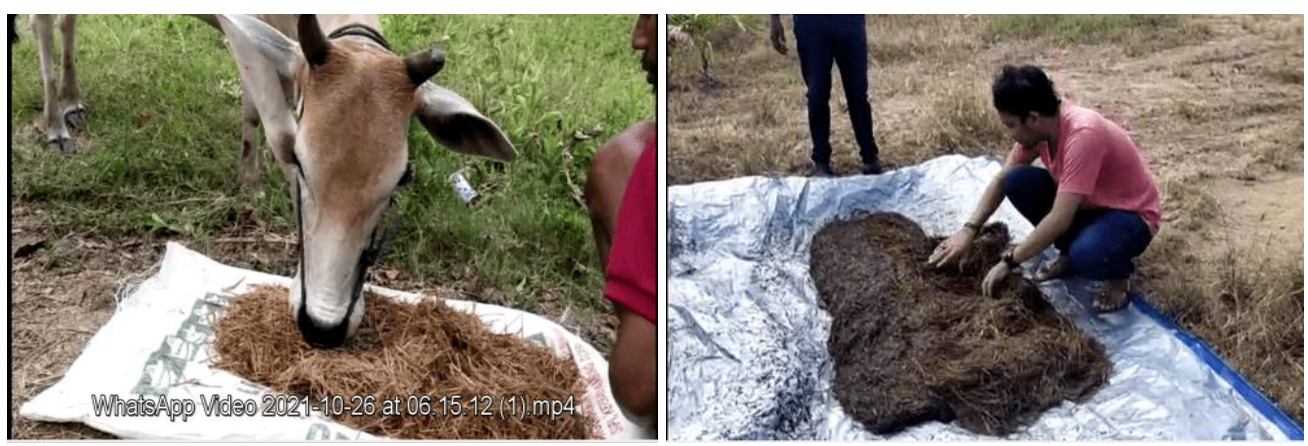

Gambar 6. Pemberian Pakan Jerami Padi Hasil Fermentasi

\section{Simpulan dan Tindak Lanjut}

Program Pengembangan Desa Mitra merupakan solusi untuk menjawab permasalahan yang dihadapi oleh peternak khususnya ketersediaan pakan ternak sapi. Pelaksanaan kegiatan ini dilakukan dengan dua metode yaitu penyuluhan dan Demonstrasi Plot (Demplot) langsung kepada peternak. Kegiatan ini berjalan sesuai rencana dan mendapat dukungan penuh dari pemerintah kampung khususnya Kampung Semangga Jaya. Melalui program ini, peternak memiliki pemahaman baru baru mengenai pemanfaatan limbah jerami padi sebagai pakan ternak sapi serta dapat bernilai ekonomis. Harapan untuk kedepanya agar selalu bersinergis antara masyarakat sebagai peternak, pemerintah kampung dan pihak akademisi untuk selalu membantu permasalahan yang dihadapi dimasyarakat serta adanya tindak lanjut kegiatan Pengabdian Pengembangan Desa Mitra melalui pengadaan mesih pemotong rumput (jerami padi) karena dalam pelaksanaan pemotongan jerami masih manual. 


\section{Daftar Pustaka}

Alvianti Bawinto, Mokoagouw, D. R., Elly, F. H., \& Manese, M. A. V. (2016). Analisis Break Even Point Ternak Sapi Potong Kelompok Tani "Sumber Hidup Sejati" Di Kecamatan Bintauna Kabupaten Bolaang Mongondow Utara. Jurnal Zootek, 36(2), 262-270.

BPS. (2020). Kabupaten Merauke Dalam Angka 2020. In Bps Kabupaten Merauke. Badan Pusat Statistik.

Eko, D., Junus, M., Nasich, \& Moch. (2012). The Effect of Urea Additive to the Content of Crude Protein and Crude Fiber of the Biogas Sludge Solids. Universitas Brawijaya.

Rachmawati, N. (2011). Penerapan Good Farming Practices Sapi Penggemukan Di Pt Lembu Jantan Perkasa Serang-Banten. Institut Pertanian Bogor.

Yanuartono, Indarjulianto, S., Purnamaningsih, H., Nururrozi, A., \& Raharjo, S. (2019). Fermentasi: Metode untuk Meningkatkan Nilai Nutrisi Jerami Padi Fermentation: Methods to Improve Nutrition Value of Rice Straw Yanuartono, S. Indarjulianto, H. Purnamaningsih, A. Nururrozi, dan S. Raharjo. Jurnal Sain Peternakan Indonesia, 14(1), 49-60. 